\title{
To study the cost of cultivation of Aloe-vera crop on the college farm v/s farmers' fields
}

\section{RAJU CHOUDHARY, PRADEEP KUMAR AND SUSHILA VISHNOI}

Abstract : Aloe (Aloe vera) is an important and traditional medicinal plant belonging to the family Liliaceae. The finding of the study revealed that total cost of cultivation of Aloe vera at farmers' field was estimated at Rs. 39753.71 per hectare. The establishment cost and maintenance cost accounted for Rs. 29671.16 and Rs. 10082.55 per hectare, respectively. Planting material cost accounted the major share in total costs on the farmer's field. Harvesting, interest on working capital, weeding and hoeing, planting cost, interest on fixed capital, transportation, farm yard manure and irrigation charges were the other major components of cost of cultivation of Aloe vera crop. The total cost of cultivation of Aloe vera was found Rs. 54038.84 per hectare at college farm excluding salary permanent employees. Of this, Rs. 42918.32 per hectare was establishment cost and Rs. 11120.52 per hectare as maintenance cost. In total cost without salary, planting material, interest on working capital, planting cost, weeding and hoeing, harvesting, transportation, interest on fixed capital and depreciation were the major components of cost at college farm. The total cost of cultivation of Aloe vera at college farm was found Rs. 1, 24,378.88 per hectare, while the salary of permanent employees was taken into account. Out of this, Rs. 96123.15 per hectare was establishment cost and Rs. 28255.73 per hectare as maintenance cost. In total cost with salary, the salary of the permanent employees was the single largest cost item at college farm. The net present worth was found Rs. 33761.1 per hectare and Rs. 30043.12 per hectare at farmer's field and college farm (excluding salary), respectively. The net present worth was estimated to be negative (Rs. -32559.52 per hectare) when salary of staff was included in the cost in the study of college farm. Various economic viability tests for investment on Aloe vera cultivation indicated that Aloe vera cultivation on farmer's field was an economically viable proposition. The cultivation of Aloe vera was not found to be an economically viable proposition if salary of permanent labour was taken into account.

Key Words : Cost of cultivation, Aloe-vera crop

How To Cite This PAPer : Choudhary, Raju, Kumar, Pradeep and Vishnoi, Sushila (2017). To study the cost of cultivation of Aloe-vera crop on the college farm v/s farmers' fields. Internat. Res. J. Agric. Eco. \& Stat., 8 (2) : 196-206, DOI : 10.15740/HAS/IRJAES/8.2/196-206.
Received : 21.03 .2017

Revised : 01.07.2017;

Accepted : 15.07.2017 